\title{
Triple Frontier: Change and Continuity on the Riverfront
}

Robert W. Wilcox ${ }^{1}$

\section{BOOK REVIEW}

Jacob Blanc and Frederico Freitas, eds. Big Water: The Making of the Borderlands between Brazil, Argentina, and Paraguay. (Tucson: University of Arizona Press, 2018). 
$\mathrm{I}$

$\mathrm{n}$ his Forward, Zephyr Frank explains that Big Water asks readers to see regions "holistically" in order to place more value on fluidity than on static lines on maps ${ }^{2}$. (p. x) This is a key focus of the volume as it examines the Triple Frontier region shared by Argentina, Brazil and Paraguay. Often neglected in the literature, the Paraná/Iguazú Rivers borderland has much more to contribute to frontier study than just its own fascinating history. As reflected in the title, which is a direct translation of the Guaraní iguazú (Spanish transliteration - iguaçu in Portuguese), the region is primarily fluvial, and its intricate and conflictive trajectory illustrates how borders not only consist of "lines on maps" but also exhibit specific characteristics that shape their histories and those of their metropolises. What transpired in the Triple Frontier over several centuries influenced the development of all three nations (most significantly that of Paraguay) and is crucial to understanding their economies and self-images today.

Eleven well-researched chapters examine this longue durée, from sixteenthcentury Spanish and Portuguese settlement and the famed Jesuit missions, through native responses and nationalist narratives, to twentieth-century migrations and economic development, including the expansion of hydroelectric projects and the restrained anarchy of Ciudad del Este, Paraguay. A range of interdisciplinary approaches characterize the study, including indigenous and peasant studies, modernization and state-formation, and migration and environmental history. The book is organized into four themes: adaptation, environment, belonging, and development. "Adaptation" examines colonial Guairá and the Jesuit missions. Shawn Michael Austin and Guillermo Wilde show how aboriginal peoples navigated the colonial borderlands, adapting to a region in constant flux by defining their own identities, which involved persistent mobility: "colonial boundaries were literally mobile Native communities." (p. 45)

The second theme introduces aspects of the region's environment. Eunice Sueli Nodari surveys the contradictions of German-Brazilian migration and environment on the Argentine/Brazilian border along the Iguazú River, while Frederico Freitas outlines the dynamic between promoted settlement and the

2 Blanc, Jacob and Frederico Freitas, eds. Big Water: The Making of the Borderlands between Brazil, Argentina, and Paraguay. (Tucson: University of Arizona Press, 2018). 
creation of national parks at the spectacular Iguazú Falls that straddle the shared border. Both emphasize the key roles national governments and colonization companies played in staking claim to the region.

The third and fourth themes address the roles of nation states and transnationalism in the region, especially as they concern identity and economy. Under "Belonging," Michael Kenneth Huner's microhistory sketches the tortured attempts of Paraguay to lay claim to its northern border with Brazil in the period before and during the disastrous Paraguayan War (1864-70). Daryle Williams appraises the attempts by all three nations to claim cultural patrimony to the Jesuit missions under the umbrella of UNESCO and Mercosur, while Evaldo Mendes da Silva explains Guaraní perspectives on their ancestral lands that have been intersected by legal lines and restrictions, yet transcended by indigenous communities, visibly and invisibly.

"Development" concentrates on the geopolitics of Paraguay and Brazil, as the massive Itaipú hydroelectric complex of the last decades of the twentieth century stimulated accelerated economic growth and socio-political transformations. Jacob Blanc's examination of Itaipú, the second largest dam in the world, emphasizes the role of geopolitics in extending the nation into the border region, particularly Brazil at the expense of Paraguay, and to the detriment of previous settlers and native peoples. However, Bridget María Chesterton explains that the Stroessner dictatorship perceived its alliance with Brazil to be liberating since it offered development alternatives to decades-old Argentine dominance. A striking consequence is the chaotic and controversial free trade zone of Cuidad del Este, which Christine Folch argues illustrates "the complexities of late capitalism." (p. 268)

Graciela Silvestri concludes the volume with an explicitly literary and philosophical consideration of modernization and tradition, depicting the region as an example of the hybridity of borderlands. Rather than subjected to destruction and recreation by exclusively outside economic and social forces, the Triple Frontier combined and refashioned largely on its own terms. This reflection highlights the essential arguments of Big Water, for the region always has been fluid, literally and figuratively. 
By their character, edited volumes have strengths and weaknesses, and Big Water is no different. Some of the chapters tend to assume prior knowledge, while migrations of certain other groups and the recent surge of soybean agroindustry are barely addressed. For environmental historians, the volume will likely disappoint since there is limited discussion of the water promised in the title. This reveals, however, that despite the tremendous importance of the region's rivers across time there has been little environmental history written about the Paraná basin, including the massive dam projects of Itaipú and Yacyretá. ${ }^{3}$ Given today's stress on river systems worldwide, I hope we see movement to rectify this lacuna.

Despite these caveats, the emphasis on fluidity guarantees the book's importance in underscoring how, like rivers, borderlands are simultaneously constant and mutable. The contributors deserve our gratitude for offering a clearer path to understanding frontiers and their inevitable migrations, conflicts, accommodations, and socioenvironmental impacts, and for permitting readers to engage with a multinational region well beyond the metropolis, yet illustrative of the modern national project writ large.

\section{REFERENCES}

Blanc, Jacob. Before the Flood: The Itaipú Dam and the Visibility of Rural Brazil. (Durham, NC: Duke University Press, 2019).

Blanc, Jacob and Frederico Freitas, eds. Big Water: The Making of the Borderlands between Brazil, Argentina, and Paraguay. (Tucson: University of Arizona Press, 2018).

Recibido: 21/06/2020

Aprobado: 26/08/2020

\footnotetext{
${ }^{3}$ Though not focused on the environment, recently Blanc has published an in-depth study of Itaipú: Jacob Blanc, Before the Flood: The Itaipú Dam and the Visibility of Rural Brazil (Durham, NC: Duke University Press, 2019).
} 